\title{
Fatty Acid Profile of New Zealand Grown Edible Pine Nuts (Pinus spp.)
}

\author{
Leo P. Vanhanen, Geoffrey P. Savage, Richard N. Hider \\ Food Group, Department of Food, Wine and Molecular Biosciences, Faculty of Agriculture and Life Sciences, Lincoln University, \\ Canterbury, New Zealand \\ Email: savage@lincoln.ac.nz
}

How to cite this paper: Vanhanen, L.P., Savage, G.P. and Hider, R.N. (2017) Fatty Acid Profile of New Zealand Grown Edible Pine Nuts (Pinus spp.). Food and Nutrition Sciences, 8, 305-315. https://doi.org/10.4236/fns.2017.83020

Received: December 14, 2016

Accepted: March 7, 2017

Published: March 10, 2017

Copyright (๑) 2017 by authors and Scientific Research Publishing Inc. This work is licensed under the Creative Commons Attribution International License (CC BY 4.0).

http://creativecommons.org/licenses/by/4.0/ (c) (i) Open Access

\begin{abstract}
Pine nuts are becoming a popular snack because of their interesting taste and positive nutritional profile. Their fatty acid profile has been reported but there is some confusion identifying named cultivars. This study presents the fatty acid profile of five different cultivars of pine nuts currently growing in the South Island of New Zealand. The data are compared to three different samples of pine nuts currently imported into NZ. Identification of the twelve different fatty acids extracted from these samples was identified by retention time using GC-FID and GC-MS methods. The peaks were further identified by comparison of the retention times with a MS Library match and their corresponding LRI value. All but two of the extracted fatty acids were identified by comparisons with a known pure fatty acid standard sample for each fatty acid. Botanical identification of the five locally grown pine nuts was confirmed by calculating the Diagnostic Index of each cultivar from its fatty acid composition.
\end{abstract}

\section{Keywords}

Pinus spp., Fatty Acid Profile, New Zealand Pine Nuts

\section{Introduction}

Pine nuts (Pinus spp.) are becoming more popular in New Zealand cuisine and their availability has increased. They have a unique taste because they contain high levels of unsaturated fatty acids. They are an excellent source of mono- and poly-unsaturated fatty acids, such as linoleic and oleic acids.

Edible nut-producing pines grow well in Asia, Europe, the Near East and North America. Several species of Pinus are known and they are grouped as soft pines (haploxylon) and hard pines (diploxylon). Pinus pinea L. is present in diploxylon pine group and its seeds are the common pine nuts traded in many markets around the world [1].

Stone pine (Pinus pinea L.) is one of the nine major tree nut species world- 
wide. Being endemic to the Mediterranean Basin, it has high economic relevance in Spain, Portugal, Italy, Tunisia and Turkey, where pine nuts are traditionally marketed and widely consumed [2].

Pine nuts are eaten raw or roasted; they are also included as ingredients in a variety of traditional dishes, such as breads, candies, sauces and cakes, as well as vegetable and meat dishes. Pine nuts are a good source of nutrients [2]. It is reported that the seeds of $P$. pinea contain 5.6\% moisture, $31.1 \%$ protein, $47.4 \%$ fat, $10.7 \%$ carbohydrate and $4.3 \%$ ash. They contain vitamins, particularly B1 and B2 and also minerals, especially potassium and phosphorus. Their high nutritional value leads nutrition experts to encourage their regular consumption in a healthy diet [1]. Regular consumption of nuts has favourable effects on blood lipids and hence can reduce the risk of coronary heart disease and sudden cardiac death, as well as beneficial effects on other cardiovascular risk factors and vascular reactivity. These positive effects are ascribed to the fatty acid profile of these nuts. The total protein content of some pine nuts is relatively high, making them a good source of plant protein in the diet [3]. In contrast to most other tree nuts, which contain mostly monounsaturated fatty acids (MUFA), primarily oleic acid, pine nuts have a predominance of polyunsaturated fatty acids (PUFA), with linoleic acid being the most abundant. Linoleic acid can be converted into cellular mediators that have an important role at the vessel level and enhance platelet aggregation (blood coagulation) [4].

Pine nut oil is the only commercially available conifer nut oil that is rich in pinolenic acid. Pinolenic acid $(\mathrm{C} 18: 3$ cis- $5,9,12)$ exerts many diverse physiological functions and has been used for the prevention or amelioration of various degenerative disorders such as hypercholesterolaemia, thrombosis and hypertension [5]. It has many biological activities, such as reducing blood pressure and attenuation of serum VLDL-TAG and VLDL cholesterol in studies using rats [6] [7].

Destaillats et al. [8] proposed using an index (Diagnostic Index) of the $\Delta 5$ olefinic acid to identify the botanical origin of pine nuts. This index could be useful to identify the origin of nuts and to determine the type of pine nut either for sale in a market or being used in a food product.

In this study, it is proposed to harvest the nuts from known cultivars of Pinus spp. grown in the South Island of New Zealand and compare these to some commercially available pine nuts. This will provide information regarding the fatty acid profile of New Zealand grown pine nuts, previously unavailable and the profile of potentially new edible nut seed cultivars.

In addition, a novel fast GLC technique will be used and confirmed, using GC-MS and series of standard mixes, to separate out the individual fatty acids and to accurately confirm their identities.

\section{Materials and Methods}

\subsection{Sample Selection}

Five different cultivars of pine nuts, Armand pine (Pinus armandii Franch), 
Mexican stone pine (Pinus cembroides Zucc.), Coulter pine (Pinus coulteri D. Don), Italian stone pine (Pinus pinea L.) and Torrey pine (Pinus torreyana Parry ex Carrière), were harvested in early winter (July 2014) at the end of the growing season in the Marlborough region, in the North-East of the South Island of New Zealand and taxonomically identified using an industry standard reference [9]. Three samples of in-shell pine nuts were purchased from the bulk bins of the local food markets in Christchurch, New Zealand. There was no cultivar identification or country of origin given to these samples of nuts but it presumed they were imported.

\subsection{Sample Preparation}

All fresh in shell pine nut samples were hand shelled, then duplicate samples of shelled nuts weighing approximately $3 \mathrm{~g}$ were finely crushed in a mortar and pestle, in duplicate. Fatty acid methyl esters were then prepared without prior lipid extraction as previously described by O'Fallon et al. [10]. This involved weighing $50 \mathrm{mg}$ of the crushed material into a $12 \mathrm{~mL}$ Kimax ${ }^{\otimes}$ screw cap test tube followed by the addition of $6.3 \mathrm{~mL}$ of methanol (HPLC grade, Fisher Scientific, Pittsburgh, PA, USA) and $0.7 \mathrm{~mL}$ of $10 \mathrm{M}$ aqueous potassium hydroxide (SigmaAldrich, St. Louis, MO, USA). Test tubes were then incubated at $55^{\circ} \mathrm{C}$ for 30 minutes, in a shaking water bath. Tubes were then cooled and $0.58 \mathrm{~mL}$ of $12 \mathrm{M}$ sulphuric acid (reagent grade, Scharlab, Barcelona, Spain) was added and the mixture was incubated again for 30 minutes at $55^{\circ} \mathrm{C}$. Tubes were then cooled on ice, then $4 \mathrm{~mL}$ of hexane (HPLC grade, Fisher Scientific, Pittsburgh, PA, USA) added and vortexed. Tubes were then centrifuged (Kubota 4000, Tokyo, Japan) at $839 \mathrm{RCF}$ for 5 minutes before transferring the hexane layer into a $2 \mathrm{~mL}$ glass vial.

\subsection{Gas Liquid Chromatography}

Methylated samples and standard mixes were analysed on a BPX-70 capillary column, $10 \mathrm{~m} \times 0.1 \mathrm{~mm}$ i.d. with a $0.2 \mu \mathrm{m}$ film thickness (SGE Analytical Science, Ringwood, VIC, Australia) installed in a Shimadzu GC-2010 system (Kyoto, Japan) gas chromatograph equipped with a flame ionization detector. The gas chromatograph conditions used followed those described by Destaillats et al. [8] with the following modifications. The split injector was operated at a ratio of 480:1 using helium as the carrier gas at a constant linear velocity of 60.8 cms-1, injecting $1 \mu \mathrm{L}$ with a total runtime of 7.90 minutes.

Confirmation and identification of peaks was conducted by analysing samples and standard mixes on a Shimadzu GCMS-QP2010 (Kyoto, Japan) gas chromatograph equipped with a mass selective detector, under the same general conditions as the Shimadzu GC-2010 system. The ion source and the interface temperatures were set at $250^{\circ} \mathrm{C}$ with the mass selective detector operated in scan mode at a mass range of 33.0 to $400 \mathrm{~m} / \mathrm{z}$.

The mass spectra for all detected peaks and standards, were compared to two mass spectral libraries, the United States National Institute of Standards and 
Technology mass spectral library [11] and the Wiley Registry ${ }^{\text {Tm }}$ of mass spectral data [12].

\subsection{Fatty Acid Identification}

The standards used for identification of sample peaks were, the pure fatty acids, 5(Z), 9(Z), 12(Z)-Octadecatrienoic acid (Cayman Chemical, Ann Arbor, MI, USA) and 5(Z), 11(Z), 14(Z)-Eicosatrienoic acid (Cayman Chemical, Ann Arbor, MI, USA), these were methylated using the same procedure as the pine nut samples. A pre-prepared mix containing 31 methylated fatty acids, Nu-Chek GLC-85 (Nu-Chek Prep, Elysian, MN, USA) was also injected.

A set of linear retention indices (LRI) was calculated for the BPX-70 capillary column using an n-alkane standard solution, C21 to C40 (Sigma-Aldrich, St. Louis, MO, USA). This involved injecting the $\mathrm{n}$-alkane standard mix using the same gas chromatographic conditions and calculating a LRI value for each fatty acid methyl ester based on the equation derived by van Den Dool \& Kratz [13] and reviewed by Zellner et al. [14].

Destaillats et al. [8] proposed the use of a diagnostic index (DI) to assist in determining the taxonomic identification of pine nuts. The DI index is based on the levels of $\Delta 5$-olefinic acids and metabolic precursors.

The formula used for the calculation of the $D I$ index was:

$$
D I=\left[\frac{(\mathrm{C} 18: 2 \mathrm{c} 5,9+\mathrm{C} 18: 3 \mathrm{c} 5,9,12+\mathrm{C} 20: 3 \mathrm{c} 5,11,14)}{(\mathrm{C} 18: 1 \mathrm{c} 9 \text { and } \mathrm{c} 11+\mathrm{C} 18: 2 \mathrm{c} 9,12+\mathrm{C} 20: 2 \mathrm{c} 11,14)}\right] \times 10
$$

\section{Results and Discussion}

For decades, fatty acid analysis by GLC has been used as a relatively rapid and simple fingerprinting method to determine the origin of oils and fats. Recently, such analysis has been applied to the taxonomy of conifers. The fatty acid composition of conifer seeds differs according to genus, subgenus, section, and subsection and thus can be used as a taxonomic marker [8] [15] [16].

In this experiment a fast GLC method was used to separate out 12 individual fatty acids from the seeds of the different Pinus spp. analysed. Using this method all the fatty acids were resolved after approximately 4.5 minutes (Figure 1). The retention times and confirmed identification of the individual fatty acids are shown in Table 1.

A peak tentatively identified as C14:0 was detected in this study, but as it made up less than $0.05 \%$ of the total fatty acids it was not reported. A C14:0 peak has been reported to be present in Pinus spp. by other researchers [2] [16] [17] but was not observed by Destaillats et al. [8] and Venkatachalam \& Sathe [18].

It was not possible to match the arachidic acid peak using the GC-MS library (Table 1), as it co-eluted with a system phthalate peak, but was identified using the Nu-Chek fatty acid methyl ester standards, based on the retention time of this peak. No pure standards or GC-MS library matches were available for gondonic and keteleeronic acids (Table 1). Their identification was based on their 


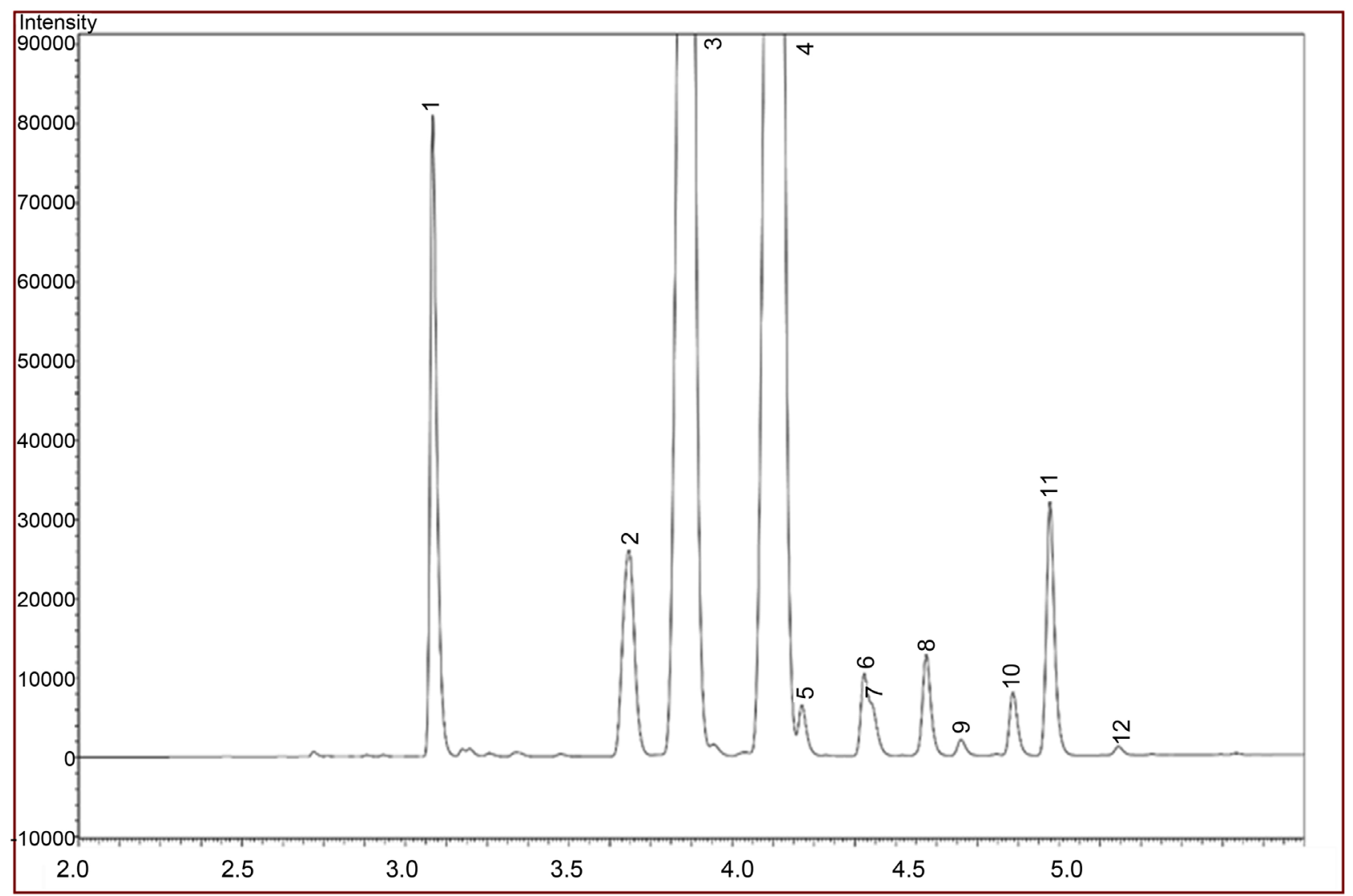

Figure 1. Typical Fast GLC chromatogram of pine nut ( $P$. pinea) fatty acid methyl esters, using a BPX-70, $10 \mathrm{~m}$ analytical column. (1) Hexadecanoic; (2) Octadecanoic; (3) c9-Octadecenoic; (4) c5,9-Octadecadienoic; (5) c9,12-Octadecadienoic; (6) c5,9,12-Octadecatrienoic; (7) c9,12,15-Octadecatrienoic; (8) Eicosanoicd; (9) c11-Eicosenoic; (10) c5,11-Eicosadienoic; (11) c11,14-Eicosadienoic; (12) c5,11,14-Ecosatrienoic.

elution order compared to the values presented by Destaillats et al. [8], who used the same analytical column. Previously Wolff and Bayard [19] and Berdeaux and Wolff [20] had correctly identified all the peaks surrounding gondonic and keteleeronic acids using pure standards or MS library matches. All the identified fatty acids had linear retention indexes (LRI) calculated for them under the conditions used for the BPX-70 column (Table 1). It can be concluded that the calculation of a LRI value for each fatty acid is a useful tool to aid its identification.

This is important as conifers can be characterised specifically by identifying a group of $\Delta 5$-olefinic fatty acids. Taxoleic acid does not have a readily available pure standard and is not available in the $\mathrm{Nu}$-Chek catalogue. This study confirms that taxoleic acid has a LRI of 2608.

This is the first time that the fatty acid composition of five Pinus spp. nut seeds collected in New Zealand has been reported (Table 1). It is also the first time that fatty acid profiles for $P$. coulteri and $P$. torreyana have been reported (Table 3). It is interesting to note the very high levels of oleic acid (50.7\%) have been observed in $P$. torreyana.

The fatty acid profiles of $P$. armandii, cembroides and pinea compare very well to the profiles reported by other researchers [8] [15] [21]. The predominant 
Table 1. Fatty acid profile standard identification for pine nuts determined by fast gas liquid chromatography, using a BPX70 column.

\begin{tabular}{|c|c|c|c|c|c|c|c|c|c|}
\hline \multirow[b]{2}{*}{ Structure } & \multirow[b]{2}{*}{ Systematic name } & \multirow[b]{2}{*}{ Trivial name } & \multirow[b]{2}{*}{ CAS No. ${ }^{a}$} & \multicolumn{2}{|c|}{$\begin{array}{l}\text { Retention time } \\
\quad \text { (minute) }\end{array}$} & \multicolumn{2}{|c|}{$\begin{array}{l}\text { Area } \\
(\%)\end{array}$} & \multirow{2}{*}{$\begin{array}{c}\text { MS Library } \\
\text { Match }^{c} \\
(\%)\end{array}$} & \multirow[t]{2}{*}{$\mathrm{LRI}^{\mathrm{d}}$} \\
\hline & & & & GC-FID & GC-MS & GC-FID & GC-MS & & \\
\hline $\mathrm{C} 16: 0$ & Hexadecanoic & Palmitic & $112-39-0$ & 2.86 & 2.87 & 4.84 & 5.46 & 97 & 2336 \\
\hline C18:0 & Octadecanoic & Stearic & $112-61-8$ & 3.33 & 3.34 & 2.87 & 3.24 & 91 & 2544 \\
\hline C18:1c9 & c9-Octadecenoic & Oleic & $112-62-9$ & 3.47 & 3.46 & 36.32 & 37.12 & 96 & 2583 \\
\hline $\mathrm{C} 18: 2 \mathrm{c} 5,9$ & c5,9-Octadecadienoic & Taxoleic & $26549-54-2^{\mathrm{b}}$ & 3.54 & 3.55 & 0.11 & 0.12 & f & 2608 \\
\hline $\mathrm{C} 18: 2 \mathrm{c} 9,12$ & c9,12-Octadecadienoic & Linoleic & $112-63-0$ & 3.68 & 3.66 & 48.93 & 47.55 & 96 & 2653 \\
\hline $\mathrm{C} 18: 3 \mathrm{c} 5,9,12$ & c5,9,12-Octadecatrienoic & Pinolenic & $38406-57-4$ & 3.76 & 3.74 & 0.67 & 0.72 & 98 & 2678 \\
\hline $\mathrm{C} 18: 3 \mathrm{c} 9,12,15$ & c9,12,15-Octadecatrienoic & Linolenic & $301-00-8$ & 3.91 & 3.90 & 0.96 & 0.86 & 93 & 2732 \\
\hline $\mathrm{C} 20: 0$ & Eicosanoic & Arachidic & $1120-28-1$ & 3.94 & 3.92 & 0.27 & 0.75 & e & 2739 \\
\hline C20:1c11 & c11-Eicosenoic & Gondoic & $2390-09-2$ & 4.07 & 4.05 & 1.12 & 1.15 & $\mathrm{f}$ & 2782 \\
\hline $\mathrm{C} 20: 2 \mathrm{c} 5,11$ & c5,11-Eicosadienoic & Keteleeronic & $126827-54-8$ & 4.15 & 4.14 & 0.19 & 0.20 & $\mathrm{f}$ & 2810 \\
\hline $\mathrm{C} 20: 2 \mathrm{c} 11,14$ & c11,14-Eicosadienoic & none & $61012-46-2$ & 4.28 & 4.26 & 0.65 & 0.61 & 89 & 2852 \\
\hline $\mathrm{C} 20: 3 \mathrm{c} 5,11,14$ & c5,11,14-Ecosatrienoic & Sciadonic & $7019-85-4^{\mathrm{b}}$ & 4.37 & 4.35 & 2.59 & 2.35 & 91 & 2881 \\
\hline
\end{tabular}

${ }^{\mathrm{a}} \mathrm{CAS}$ numbers are for the methyl ester of the fatty acid. ${ }^{\mathrm{b}} \mathrm{CAS}$ numbers are for the fatty acid. ${ }^{\mathrm{c} M a s s}$ Spectral Libraries NIST 11 [11] and Wiley $10^{\text {th }}$ edition [12]. ${ }^{\mathrm{d}}$ Linear Retention Index (LRI) values calculated from Alkane mix $\mathrm{C}_{21}-\mathrm{C}_{40}$, using equation determined by van Den Dool and Kratz [13]. ${ }^{\mathrm{e}} \mathrm{No}$ MS library match. Co-elution with diethyl phthalate (system peak). Identified using Nu-Chek Prep Inc. GLC-85. ${ }^{\mathrm{f}}$ No MS library match. Identified using the description in Destaillats et al. [8].

fatty acids were oleic and linoleic acid, present in the ranges of 19.63 to 50.66 and $35.73 \%$ to $51.70 \%$ respectively.

The New Zealand pine nuts contained two fatty acids from the cis-5-unsaturated polymethylene-interrupted ( $\Delta 5$-UPIFA) family, namely C18: 3 cis-5, 9, 12 (pinolenic acid) and C20: 3 cis-5, 11, 14 (sciadonic acid). The principal $\Delta 5$-olefinic acid was pinolenic acid, ranging from $0.24 \%$ to $18.44 \%$ for all the samples measured.

The DI was calculated for all the New Zealand grown pine nuts and the market samples (Table 2). The DI for the New Zealand grown nuts, $P$. armandi, cembroides and pinea were consistent with previously reported values (Table 3).

The market samples, purchased and presumably imported into New Zealand, had fatty acid profiles and DI values very different from all of the New Zealand grown pine nuts. The DI values of these imported nuts are close to either $P$. armandi or $P$. coulteri.

Destaillats et al. [8] proposed the use of the DI values to determine the taxonomic difference between Pinus cultivars and they suggest that a blend or mixture of nuts could be reconciled using the diagnostic index.

Fardin-Kia et al. [15] has also tested this methodology, but concluded that DI alone is perhaps not accurate enough and there is potential for overlap in the DI index numbers in some cases.

The most commonly grown variety grown for consumption is $P$. pinea. New Zealand grown $P$. pinea contains a low level of pinolenic acid. Pasman et al. [22] showed that the $P$. pinea pinolenic acid content could range from $0.3 \%$ to $15 \%$. 
Table 2. Botanical identification using the diagnostic index value (DI $\left.{ }^{\star}\right)$ and fatty acid profile of Pinus spp. grown in New Zealand and purchased in local markets.

\begin{tabular}{|c|c|c|c|c|c|c|c|c|}
\hline Fatty acid & $\begin{array}{c}\text { Chinese } \\
\text { white pine } \\
(P . \text { armandii) }\end{array}$ & $\begin{array}{c}\text { Mexican pine } \\
(P . \text { cembroides })\end{array}$ & $\begin{array}{l}\text { Coulter pine } \\
(P . \text { coulteri })\end{array}$ & $\begin{array}{c}\text { Stone pine } \\
(P \text { p pinea })\end{array}$ & $\begin{array}{l}\text { Torrey pine } \\
\text { (P. torreyana) }\end{array}$ & $\begin{array}{c}\text { Market } \\
\text { sample } \\
\quad \# 1\end{array}$ & $\begin{array}{c}\text { Market } \\
\text { sample } \\
\# 2\end{array}$ & $\begin{array}{c}\text { Market } \\
\text { sample } \\
\text { \#3 }\end{array}$ \\
\hline $\mathrm{C} 16: 0$ & 3.27 & 4.46 & 3.36 & 5.12 & 5.26 & 4.19 & 4.35 & 4.53 \\
\hline $\mathrm{C} 18: 0$ & 1.89 & 1.83 & 1.14 & 3.37 & 1.96 & 2.26 & 1.92 & 2.01 \\
\hline C18:1c9 & 19.63 & 42.38 & 36.36 & 36.11 & 50.66 & 23.99 & 24.97 & 26.78 \\
\hline $\mathrm{C} 18: 2 \mathrm{c} 5,9$ & 2.46 & 0.05 & 2.27 & 0.11 & 0.75 & 1.53 & 1.82 & 1.92 \\
\hline $\mathrm{C} 18: 2 \mathrm{c} 9,12$ & 51.70 & 41.95 & 39.74 & 49.98 & 35.73 & 46.08 & 44.10 & 46.99 \\
\hline $\mathrm{C} 18: 3 \mathrm{c} 5,9,12$ & 17.93 & 0.24 & 11.75 & 0.40 & 2.35 & 18.44 & 13.10 & 13.94 \\
\hline C18:3c9,12,15 & 0.17 & 0.17 & 0.35 & 0.74 & 0.23 & 0.17 & 0.10 & 0.10 \\
\hline C20:0 & 0.25 & 0.26 & 0.25 & 0.34 & 0.41 & 0.21 & 0.21 & 0.22 \\
\hline C20:1c11 & 0.72 & 0.69 & 0.79 & 0.92 & 1.19 & 0.97 & 1.04 & 1.11 \\
\hline $\mathrm{C} 20: 2 \mathrm{c} 5,11$ & 0.14 & 0.04 & 0.40 & 0.15 & 0.21 & - & - & - \\
\hline $\mathrm{C} 20: 2 \mathrm{c} 11,14$ & 0.58 & 0.38 & 0.29 & 0.62 & 0.22 & 0.48 & 0.51 & 0.54 \\
\hline C20:3c5, 11,14 & 1.26 & 0.41 & 1.33 & 2.35 & 1.01 & 0.97 & 0.87 & 0.94 \\
\hline DI & 3.05 & 0.08 & 2.32 & 0.35 & 0.50 & 2.96 & 2.26 & 2.26 \\
\hline
\end{tabular}

${ }^{*} \mathrm{DI}=[(\mathrm{C} 18: 2 \mathrm{c} 5,9+\mathrm{C} 18: 3 \mathrm{c} 5,9,12+\mathrm{C} 20: 3 \mathrm{c} 5,11,14) /(\mathrm{C} 18: 1 \mathrm{c} 9 \mathrm{and} \mathrm{c} 11+\mathrm{C} 18: 2 \mathrm{c} 9,12+\mathrm{C} 20: 2 \mathrm{c} 11,14)] \times 10$.

In a Mediterranean environment, Nasri et al. [17] reports a range from trace to $3.7 \%$ of pinolenic acid in pine nuts. In addition, $P$. pinea can have significantly lower levels of $\Delta 5$-olefinic acids when compared to most other pine species that grow at higher altitudes or in colder regions. Perhaps this is indicative of some relationship between the $\Delta 5$ unsaturation of the fatty acids in pine nuts and their resistance to cold conditions [23].

Pine nuts are a nutritious food rich in fatty acids fats that are now considered to be important in a healthy diet. The favourable fatty acid composition of pine nuts has been promoted by Ros \& Mataix [4], the content of PUFA is higher than the MUFA (oleic acid), and mostly PUFA including linoleic acid. Together, MUFA and PUFA contribute around $91 \%$ of the energy from fat [3]. In addition, Pine nuts contain a lower concentration of saturated fatty acids. In general, pine seeds are rich in oils; however, their contents vary due to differences in species and environmental factors [2].

Conversely, a growing body of health-beneficial effects are attributed to MUFA and PUFA, notably n-3 and n-6 FA contents [17], in association with improved lipid profiles, a lower potency of intermediate biomarkers of atherosclerosis, improvement of endothelial function and lesser incidence of cardiovascular diseases [4]. Compared to other commonly eaten tree-nuts New Zealand-grown pine nuts are an excellent source of $\alpha$-linolenic acid and this fatty acid is known to have number of cardioprotective actions, clearly demonstrated anti-atherosclerotic properties such as anti-thrombotic, anti-inflammatory and anti-arrhythmic properties [4]. 
Table 3. Taxonomy and diagnostic index value (DI) of species in the Pinus genus.

\begin{tabular}{|c|c|}
\hline Species & Diagnostic index (DI) \\
\hline P. aristata & $2.12^{\mathrm{c}}$ \\
\hline P. armandii & $2.80^{\mathrm{b}}, 2.91^{\mathrm{b}}, 2.93^{\mathrm{a}}, 2.95^{\mathrm{a}}, 2.95^{\mathrm{e}}, 2.96 \mathrm{~b}, 2.98^{\mathrm{b}}, 3.00 \mathrm{~b}, 3.03^{\mathrm{b}}, 3.05^{\#}, 3.16^{\mathrm{b}}$ \\
\hline P. canariensis & $0.75^{\mathrm{c}}$ \\
\hline P. cembra & $3.06^{\mathrm{b}} 3.23^{\mathrm{e}}$ \\
\hline P. cembroides & $0.09^{\mathrm{d}}, 0.08^{\#}$ \\
\hline P. coulteri & $2.32^{\#}$ \\
\hline P. edulis & $0.09^{\mathrm{b}}, 0.09^{\mathrm{e}}$ \\
\hline P. gerardiana & $0.05^{\mathrm{b}}, 0.08^{\mathrm{b}}, 0.10^{\mathrm{a}}$ \\
\hline P. griffithii & $3.70^{\mathrm{b}}$ \\
\hline P. kesiya & $4.24^{\mathrm{b}}$ \\
\hline P. koraiensis & $2.13^{\mathrm{b}}, 2.26^{\mathrm{b}}, 2.41^{\mathrm{e}}, 2.50^{\mathrm{a}}, 2.55^{\mathrm{a}}, 2.53^{\mathrm{b}}$ \\
\hline P. lambertiana & $1.4^{\mathrm{c}}, 1.95^{\mathrm{b}}$ \\
\hline P. massoniana & $3.17^{\mathrm{a}}, 4.12^{\mathrm{c}}$ \\
\hline P. merkusii & $2.06^{\mathrm{e}}$ \\
\hline P. monophylla & $0.06^{\mathrm{e}}, 0.19^{\mathrm{b}}$ \\
\hline P. monticola & $3.86^{\mathrm{c}}$ \\
\hline P. nigra & $4.13^{\mathrm{e}}$ \\
\hline P. nigra austriaca & $4.01^{\mathrm{c}}$ \\
\hline P. parviflora & $3.46^{\mathrm{c}}$ \\
\hline P. patula & $4.17^{\mathrm{c}}$ \\
\hline P. peuce & $4.72^{\mathrm{c}}$ \\
\hline$P$. pinaster & $2.32^{\mathrm{e}}$ \\
\hline P. pinea & $0.26^{\mathrm{a}}, 0.27^{\mathrm{a}}, 0.27^{\mathrm{b}}, 0.33^{\mathrm{a}}, 0.35^{\#}, 0.19-0.42^{\mathrm{f}}$ \\
\hline P. pumila & $3.32^{\mathrm{b}}, 3.28^{\mathrm{b}}$ \\
\hline P. resinosa & $4.49^{\mathrm{c}}$ \\
\hline P. sibirica & $3.11^{\mathrm{e}}, 3.21^{\mathrm{b}}, 3.43^{\mathrm{b}}$ \\
\hline P. strobus & $4.71^{\mathrm{e}}$ \\
\hline P. sylvestris & $5.05^{\mathrm{e}}$ \\
\hline P. tabuliformis & $3.98^{\mathrm{b}}$ \\
\hline P. torreyana & $0.5^{\#}$ \\
\hline P. wallichiana & $3.90^{\mathrm{b}}$ \\
\hline P. yunnanesis & $4.33^{\mathrm{b}}$ \\
\hline
\end{tabular}

${ }^{\mathrm{a}}[8] ;{ }^{\mathrm{b}}[15] ;{ }^{\mathrm{c}}[16] ;{ }^{\mathrm{d}}[21] ;{ }^{\mathrm{e}}[24] ; \mathrm{f}[17] ;{ }^{\mathrm{t}}$ This study; ${ }^{\text {cde, }, \mathrm{f}} \mathrm{DI}$ index calculated from published fatty acid values.

\section{Conclusions}

This study has confirmed the identity of 10 of the 12 fatty acid methyl esters resolved in the chromatogram of Pinus spp., with two fatty acids confirmed by comparison to previous studies. This study also verified and confirmed the effective use of a fast GLC technique combined with a simple methylation technique, as a fast and easy technique in determining the fatty profile of pine nut seeds. LRI values have been reported for all fatty acids to aid future identification 
of fatty acids separated using a BPX-70 column.

This is the first time that the fatty acid profile and LRI values for five New Zealand grown pine nuts have been reported and their identity confirmed by comparison with previously published DI values (Table 3 ). This study has also reported fatty acid profile for $P$. coulteri and $P$. torreyana. Torrey pine is noted to have the highest oleic acid of all of the New Zealand pine nuts (50.66\%) while Coulter pines have a high pinolenic acid content (11.75\%).

New Zealand grown pine nuts contain high levels of unsaturated fatty acids, oleic and linoleic acid. They also contain several $\Delta 5$-olefinic fatty acids, taxoleic, pinolenic, keteleeronic and sciadonic which are characteristic fatty acids found in many gymnosperms.

The authors suggest that further investigation is required to determine the edibility of $P$. coulteri and $P$. torreyana nuts and especially Coulter pine nuts as they have a high in pinolenic acid content.

\section{Acknowledgements}

The authors wish to thank Lee Paterson of Pinoli, Ltd., Marlborough, New Zealand for supplying the Pine nuts and Jason Breitmeyer for his expert advice on GC-MS analysis.

\section{References}

[1] Nergiz, C. and Dönmez, İ. (2004) Chemical Composition and Nutritive Value of Pinus pinea L. Seeds. Food Chemistry, 86, 365-368. https://doi.org/10.1016/j.foodchem.2003.09.009

[2] Evaristo, I., Batista, D., Correia, I., Correia, P. and Costa, R. (2010) Chemical Profiling of Portuguese Pinus pinea L. Nuts. Journal of the Science of Food and Agriculture, 90, 1041-1049. https://doi.org/10.1002/jsfa.3914

[3] Brufau, G., Boatella, J. and Rafecas, M. (2006) Nuts: Source of Energy and Macronutrients. British Journal of Nutrition, 96, S24-S28.

https://doi.org/10.1017/BJN20061860

[4] Ros, E. and Mataix, J. (2006) Fatty Acid Composition of Nuts-Implications for Cardiovascular Health. British Journal of Nutrition, 96, 29-35. https://doi.org/10.1017/BJN20061861

[5] Adhikari, P., Zhu, X.M., Gautam, A., Shin, J.A., Hu, J.N., Lee, J.H., Akoh, C.C. and Lee, K.T. (2010) Scaled-Up Production of Zero-Trans Margarine Fat Using Pine Nut Oil and Palm Stearin. Food Chemistry, 119, 1332-1338. http://dx.doi.org/10.1016/j.foodchem.2009.09.009

[6] Asset, G., Staels, B., Wolff, R.L., Baugé, E., Madj, Z., Fruchart, J.C. and Dallongeville, J. (1999) Effects of Pinus pinaster and Pinus koraiensis Seed Oil Supplementation on Lipoprotein Metabolism in the Rat. Lipids, 34, 39-44.

http://dx.doi.org/10.1007/s11745-999-335-2

[7] Sugano, M., Ikeda, I., Wakamatsu, K. and Oka, T. (1994) Influence of Korean Pine (Pinus koraiensis)-Seed Oil Containing cis-5,cis-9,cis-12-Octadecatrienoic Acid on Polyunsaturated Fatty Acid Metabolism, Eicosanoid Production and Blood Pressure of Rats. British Journal of Nutrition, 72, 775-783.

https://doi.org/10.1079/BJN19940079

[8] Destaillats, F., Cruz-Hernandez, C., Giuffrida, F. and Dionisi, F. (2010) Identifica- 
tion of the Botanical Origin of Pine Nuts Found in Food Products by Gas-Liquid Chromatography Analysis of Fatty Acid Profile. Journal of Agricultural and Food Chemistry, 58, 2082-2087. https://doi.org/10.1021/jf9041722

[9] Dallimore, W., Jackson, A.B. and Harrison, S.G. (1966) A Handbook of Coniferae and Ginkgoaceae. Revised Edition, Edward Arnold, London.

[10] O’Fallon, J.V., Busboom, J.R., Nelson, M.L. and Gaskins, C.T. (2014) A Direct Method for Fatty Acid Methyl Ester Synthesis: Application to Wet Meat Tissues, Oils, and Feedstuffs. Journal of Animal Science, 85, 1511-1521. https://doi.org/10.2527/jas.2006-491

[11] NIST/EPA/NIH Mass Spectral Library (NIST 11) (2012) Mass Spectral Database for Windows, Standard Reference Data Program, U.S. Department of Commerce. National Institute of Standards and Technology, Gaithersburg.

[12] Wiley (2013) Wiley Registry of Mass Spectral Data. 10th Edition, John Wiley \& Sons, Hoboken.

[13] Van Den Dool, H. and Kratz, P.D. (1963) A Generalization of the Retention Index System Including Linear Temperature Programmed Gas-Liquid Partition Chromatography. Journal of Chromatography A, 11, 463-471. https://doi.org/10.1016/S0021-9673(01)80947-X

[14] Zellner, B.D., Bicchi, C., Dugo, P., Rubiolo, P., Dugo, G. and Mondello, L. (2008) Linear Retention Indices in Gas Chromatographic Analysis: A Review. Flavour and Fragrance Journal, 23, 297-314. https://doi.org/10.1002/ffj.1887

[15] Fardin-Kia, A.R., Handy, S.M. and Rader, J.I. (2012) Characterization of Pine Nuts in the U.S. Market, Including Those Associated with "Pine Mouth", by GC-FID. Journal of Agricultural and Food Chemistry, 60, 2701-2711. https://doi.org/10.1021/jf205188m

[16] Wolff, R.L., Comps, B., Marpeau, A.M. and Deluc, L.G. (1997) Taxonomy of Pinus Species Based on the Seed Oil Fatty Acid Compositions. Trees, 12, 113-118. https://doi.org/10.1007/pl00009698

[17] Nasri, N., Khaldi, A., Fady, B. and Triki, S. (2005) Fatty Acids from Seeds of Pinus pinea L.: Composition and Population Profiling. Phytochemistry, 66, 1729-1735. https://doi.org/10.1016/j.phytochem.2005.05.023

[18] Venkatachalam, M. and Sathe, S.K. (2006) Chemical Composition of Selected Edible Nut Seeds. Journal of Agricultural and Food Chemistry, 54, 4705-4714. https://doi.org/10.1021/jf0606959

[19] Wolff, R.L. and Bayard, C.C. (1995) Fatty Acid Composition of Some Pine Seed Oils. Journal of the American Oil Chemists' Society, 72, 1043-1046. https://doi.org/10.1007/BF02660719

[20] Berdeaux, O. and Wolff, R.L. (1996) Gas-Liquid Chromatography-Mass Spectrometry of the 4,4-Dimethyloxazoline Derivatives of $\Delta 5$-Unsaturated PolymethyleneInterrupted Fatty Acids from Conifer Seed oils. Journal of the American Oil Chemists' Society, 73, 1323-1326.https://doi.org/10.1007/BF02525463

[21] Wolff, R.L. and Marpeau, A.M. (1997) $\Delta 5$-Olefinic Acids in the Edible Seeds of Nut Pines (Pinus cembroides edulis) from the United States. Journal of the American Oil Chemists' Society, 74, 613-614.https://doi.org/10.1007/s11746-997-0191-0

[22] Pasman, W.J., Heimerikx, J., Rubingh, C.M., van den Berg, R., O’Shea, M., Gambelli, L., Hendriks, H.F.J., Einerhand, A.W.C., Scott, C., Keizer, H.G. and Mennen, L.I. (2008) The Effect of Korean Pine Nut Oil on in Vitro CCK Release, on Appetite Sensations and on Gut Hormones in Post-Menopausal Overweight Women. Lipids in Health and Disease, 7, 10. https://doi.org/10.1186/1476-511X-7-10 
[23] Wolff, R.L., Comps, B., Deluc, L.G. and Marpeau, A.M. (1998) Fatty Acids of the Seeds from Pine Species of the Ponderosa-Banksiana and Halepensis Sections. The Peculiar Taxonomic Position of Pinus pinaster. Journal of the American Oil Chemists' Society, 75, 45-50. https://doi.org/10.1007/s11746-998-0008-9

[24] No, D.S. and Kim, I.H. (2013) Pinolenic Acid as a New Source of Phyto-Polyunsaturated Fatty Acid. Lipid Technology, 25, 135-138.

https://doi.org/10.1002/lite.201300278

Submit or recommend next manuscript to SCIRP and we will provide best service for you:

Accepting pre-submission inquiries through Email, Facebook, LinkedIn, Twitter, etc. A wide selection of journals (inclusive of 9 subjects, more than 200 journals) Providing 24-hour high-quality service User-friendly online submission system Fair and swift peer-review system Efficient typesetting and proofreading procedure Display of the result of downloads and visits, as well as the number of cited articles Maximum dissemination of your research work

Submit your manuscript at: http://papersubmission.scirp.org/

Or contact fns@scirp.org 